\title{
PENDIDIKAN LINGKUNGAN HIDUP BAGI GENERASI MELENIAL PADA ERA 4.0
}

\author{
(Kasus Pengelolaan Hutan di Desa Adat Tenganan)
}

\author{
Oleh: \\ Ni Wayan Karmini, Made Yuliani Wiana, Wayan Sukarma \\ karmini.niwayan@yahoo.com \\ Universitas Hindu Indonesia \\ Denpasar
}

Proses Review 21 Agustus-03 September, Dinyatakan Lolos 25 September 2019

\begin{abstract}
This scientific work aims to discuss the form of forest management, as well as the implications and their meaning in environmental education for millennial generation in the 4.0 era. As a form of qualitative study, research data were obtained through observation, literature studies, and in-depth interviews with 11 informants, namely observers of Balinese cultural tourism and traditional leaders of Tenganan Pegringsingan Village. The collected data were analyzed descriptively-qualitatively. The results of the study showed that the form of forest management in the Tenganan Pegringsingan Village strengthened by the implementation of local wisdom (awig-awig). The local Balinese community carries out these awig-awig. They do not damage the potential of forest flora and fauna, and utilize forest products in an adaptive manner. The application of local wisdom (awig-awig) in managing the Tenganan forests in an adaptive manner has direct implications in fostering behaviors that support environmental conservation efforts. Adaptive forest management has a meaning for environmental education for millennial generations. The involvement of millennial generation in efforts to preserve the environment needs to be continuously developed.
\end{abstract}

Keywords:

\begin{abstract}
Abstrak
Karya ilmiah ini bertujuan membahas bentuk pengelolaan hutan, serta implikasi dan maknanya dalam pendidikan lingkungan hidup bagi generasi milenial pada era 4.0.Sebagai bentuk kajian kualitatif, data penelitian diperoleh melalui observasi, studi pustaka, dan wawancara mendalam dengan 11 informan, yakni pemerhati pariwisata budaya Bali dan pemuka masyarakat adat Desa Tenganan Pegringsingan. Data yang terkumpul dianalisis secara deskriptif-kualitatif.Hasil kajian menunjukkan bahwa bentuk pengelolaan hutan di Desa Adat Tenganan diperkuat dengan implementasi kearifan lokal (awig-awig). Komunitas Bali aga setempat melaksanakan awig-awig tersebut. Mereka tidak merusak potensi flora dan fauna hutan, serta memanfaatkan hasil hutan
\end{abstract}


secara adaptif. Penerapan kearifan lokal (awig-awig) dalam mengelola hutan Tenganan secara adaptif memiliki implikasi langsung dalam menumbuhkan perilaku yang mendukung upaya pelestarian lingkungan hidup. Pengelolaan hutan secara adaptif memiliki makna bagi pendidikan lingkungan hidup untuk generasi milenial. Pelibatan generasi milenial dalam upaya pelestarian lingkungan hidup perlu terus dikembangkan.

Kata Kunci: Hutan Tenganan, pelestarian lingkungan hidup, generasi milenial,era 4.0

\section{PENDAHULUAN}

Pariwisata merupakan sebuah sektor unggulan dunia. Pariwisata diperkirakan World Tourism Organization (WTO) dalam Sabri (2006) sebagai sektor prospektif yang akan terus berkembang seiring dengan kunjungan wisata mencapai 1,6 miliar keberbagai belahan dunia pada tahun 2020. Dalam 30 tahun terakhir, Budeanu (2007) mengatakan bahwa pariwisata sudah berhasil menjadi sektor primadona dan mengalami perkembangan signifikan.

Menurut Wang and Wall (2005), perkembangan pariwisata dipengaruhi kuat oleh faktor lingkungan sebagai suatu industri. Buck dan Law dalam Pitana dan Gayatri (2005) memandang citra dari industri pariwisata menjadi semakin prioritas sejalan dengan meningkatnya intensitas dalam pertumbuhan pasar global. Citra pariwisata menjadi sesuatu yang diperjuangkan dalam meraih loyalitas wisatawan melalui penguatan kesan secara langsung dan iklan (Piskorski, 2011).

Pariwisata Bali merupakan ikon pariwisata Indonesia di mata dunia.Pariwisata Bali menjadi barometer perkembangan pariwisata nasional karena dianggap sudah berkembang pesat dan berkontribusi signifikan dalam pembangunan nasional. Wihadanto dan Firmansyah (2013) mengatakan pariwisata sebagai sektor unggulan daerah Bali. Pariwisata Bali pun sudah mulai berkembang sejak Bali menjadi selalu menjadi buah bibir orang Belanda ketika era kolonial di Indonesia (Bungin, 2015). Pariwisata Bali semakin dikenal setelah ditemukan kedekatan diantara budaya jawa dengan budaya Bali pada tahun 1930 (Picard, 2006). Demikian perkembangan pariwisata budaya menjadi representasi dari pariwisata Bali, dimana jasa dan produk wisata budaya Bali paling diminati wisatawan ketika di Bali dan masih selalu ditawarkan kepada wisatawan.

Penetapan pariwisata budaya Bali dalam pembangunan pariwisata Bali diresmikan berdasarkan peraturan daerah provinsi Bali nomor 2 tahun 2012 tentang Kepariwisataan Budaya Bali. Peraturan ini menggantikan Peraturan Daerah Provinsi Daerah Tingkat I Bali Nomor 3 Tahun 1991 tentang Pariwisata Budaya yang dianggap sudah tidak sesuai lagi dengan kebijakan kepariwisataan nasional. Sejalan dengan kebijakan kepariwisataan nasional, pembangunan pariwisata Bali juga mengembangkan ekowisata.

Ekowisata merupakan bentuk wisata konservatif untuk kesejahteraan daerah dan kelestarian lingkungan alam (Damanik dkk, 2006). Ekowisata merupakan bentuk solutif untuk memperbaiki citra negatif dari pembangunan pariwisata. Ricardson dan Fluker (2004) mengatakan bahwa pariwisata sudah berdampak terhadap perubahan lingkungan. Kerusakan, ketidakseimbangan lingkungan akibat semakin minimnya lahan hijau pascapembangunan pariwisata menimbulkan citra negatif bagi pariwisata (Budeanu, 2007). Sebagai pariwisata alternatif, Koslowski dan Travis dalam Kusuma Negara (2010) mengatakan bahwa ekowisata sebagai tipikal kegiatan wisata yang berpihak pada keberlangsungan ekologis dalam pembangunan pariwisata.

Sektor pariwisata yang menghandalkan potensi lingkungan alam (ekowisata) merupakan tipe wisata yang sukses dibangun dan berlangsung berkelanjutan di desa adat Tenangan Bali. Mengingat Tenganan dikenal sebagai sebuah desa Bali Aga karena memiliki tradisi budaya Bali Aga yang berbeda dengan desa-desa lain di Bali, sehingga sangat potensial 
dikembangkan pariwisata budayasecara berkelanjutan. Namun, pada desa adat Tenganan justru berkembang ekowisata yang sampai saat ini juga mampu berkelanjutan di desa adat Tenganan, Bali.

Keberadaan ekowisata di era revolusi Industri 4.0 dewasa ini menjadi semakin penting. Revolusi Industri 4.0 atau The Fourth Industrial Revolution, era dimana teknologi digitalisasi dan otomatisasi, kian memainkan peran penting dalam berbagai kegiatan ekonomi, terutama di sektor kegiatan industri manufaktur. Ada beberapa teknologi kunci yang mewarnai era ini, seperti kecerdasan buatan (artificial intelligence), Internet of Things (IoT), super komputer, rekayasa genetika, teknologi otomatisasi, dan beberapa teknologi lain berbasis digital.

Komitmen menjaga harmonisasi bumi dan lingkungan hidup, bisa lebih dioptimalkan melalui pemanfaatan teknologi informasi berbasis solusi Internet of Things (IoT) melalui Nusantara Earth Observation Network (NEOnet)-Kedeputian Bidang Teknologi Pengembangan Sumberdaya Alam (TPSA)-BPP Teknologi. Optimalisasi adopsi konsep Industri 4.0 untuk kebumian (Bumi 4.0) serta untuk pengelolaan lingkungan hidup dan sumber daya alam (SDA) sesuai dengan prinsip kelestarian alam, berpotensi besar mendukung upaya pemerintah menuju Revolusi Industri 4.0 (Anonim, 2018, Ristek Dikti, 2019).

Desa Adat Tenganan berhasil mengelola ekowisata karena masyarakat setempat berhasil melaksanakan kearifan lokal yakniawig-awig (hukum adat) dalam mengelola hutan setempat secara adaptif. Pengelolaan hutan Tenganan secara adaptif telah menjadikan Desa Adat Tenganan sebagai salah satu pudsat ekowisata di wilayah Kabupaten Karangasem, Bali Timur, Sehubungan dengan hal ini, maka karya ilmiah ini membahas: (1) Bagaimanakah bentuk pengelolaan hutan di Desa Sadat Tenganan?' (2) Bagaimana implementasi pengelolaan hutan tersebut bagi pelestarian lingkungan hidup?(3) Apa makna pengelolaan hutan yang adaptif di tenganan bagi pendidikan lingkungan hidup untuk generasi milenial?

\section{METODE}

Karya ilmiah ini merupakan hasil dari penelitian kualitatif tentang pengelolaan hutan di dewa adat Tenganan.Data penelitian diperoleh melalui observasi, studi pustaka, dan wawancara mendalam dengan 11 informan, yakni pemerhati pariwisata budaya Bali dan prajuru adat Desa Tenganan Pegringsingan.Data yang terkumpul dianalisis secara deskriptif-kualitatif. Diharapkan, melalui publikasai ini dapat dipetik sebuah pembelajaran berharga bahwa kearifan lokal yang berupa hukum adat (awig-awig) memiliki kedudukan yang penting dalam kehidupan masyarakat adat untuk mendukung upaya pelestarian lingkungan hidup dan pembangunan pariwisata yang berkelanjutan.

\section{PEMBAHASAN}

\subsection{Bentuk Pengelolaan Hutan Tenganan}

Komunitas adat Desa Tenganan adalah bagian dari masyarakat Bali asli yang juga disebut sebagai "Bali Aga". Jumlah penduduk Desa Tenganan sampai dengan 31 Desember 2018 adalah $1372 \mathrm{KK}$ atau 4620 jiwa, terdiri dari 2248 jiwa laki-laki dan 2372 jiwa perempuan. Sebagai suatu kesatuan masyarakat hukum adat, karma Desa Adat Tenganan Pegringsingan memiliki awig-awig, yaknihukum adat tertulis yang memuat seperangkat kaedah-kaedah sebagai pedoman bertingkah laku dalam masyarakat dan disertai dengan sanksi-sanksi yang dilaksanakan secara tegas dan nyata. Para leluhur penduduk desa ini menyusun awig-awig pada sekitar abad ke 11, dan dibakukan dalam sebuah 'buku suci' 58 halaman yang ditulis dalam bahasa Bali.Awig-awig desa adat Tenganan Pegringsingan dengan sanksi-sanksi yang tegas dan nyata ternyata telah mampu mengatur hubungan manusia dan kesinambungan pemanfaatan sumber daya alam.

Desa Adat Tenganan Pegringsingan memiliki hutan seluas 255,840 hektar.Kondisi hutan desa setempat masih relatif asri karena kehidupan flora (tetumbuhan, pepohonan, buah-buahan) dan fauna (binatang ternak) yang ada masih terlindungi karena pengelolaannya dilakukan dengan menerapkan awig-awig secara 
konsisten. Segenap krama desa adat setempat mematuhi dan menjalankan isi awig-awig Desa Adat Tenganan Pegringsingan tersebut.

Menurur Astiti (2005: 2), pada prinsipnya awig-awig mengatur tentang parhyangan, (sebagai pencerminan hubungan manusia dengan Tuhan, pawongan (sebagai pencerminan hubungan manusia dengan manusia) dan palemahan (sebagai pencerminan hubungan manusia dengan lingkungannya). Di sini, awigawig berperan sebagai alat pengendalian sosial. Selain itu, dalam upaya pengelolaan hutan di Desa Adat Tenganan Pegringsingan juga ditempuh melalui tindakan yang bersifat represif, yakni penegakan sanksi kepada para pelanggarnya.Dengan penerapan sanksi yang tercantum dalam awig-awig kepada si pelaku diharapkan kaidah-kaidah yang berlaku diharapkan dapat kembali ditaati, dan pola-pola hubungan yang terganggu akibat penyimpangan tersebut dapat dipulihkan seperti sedia kala (Senasri, 2008). Sanksi yang tertuang dalam awig-awig dapat dibedakan menjadi dua yaitu : sanksi yang bersifat fisik antara lain berupa peringatan, denda, penutupan saluran air, pencabutan hak sebagai penggarap, dan sanksi yang bercorak religius berupa kewajiban untuk melakukan upacara tertentu untuk mengembalikan keseimbangan lingkungan hidup, termasuk keberadaan hutan di desa setempat (lihat Tabel 1).

Tabel 3.1

Awig-Awig terkait Pengeloalaan Hutan Wisata Desa Tenganan Pegringsingan

\begin{tabular}{|l|l|l|}
\hline Pasal & \multicolumn{1}{|c|}{ Substansi/isi } & \multicolumn{1}{|c|}{ Sanksi } \\
\hline 3 & Mencuri hasil kebun & $\begin{array}{l}\text { Mengganti 2 kali lipat } \\
\text { dan denda uang sebesar } \\
2.000\end{array}$ \\
\cline { 2 - 3 } & $\begin{array}{l}\text { Mencuri mas, perak, } \\
\text { permata, mirah, intan ratna }\end{array}$ & $\begin{array}{l}\text { Mengganti 2 kali lipat } \\
\text { dan denda uang sebesar } \\
10.000\end{array}$ \\
\hline \multirow{10}{*}{} & $\begin{array}{l}\text { Pengungsi (orang luar } \\
\text { desa) dilarang memungut } \\
\text { reruntuhan buah-buahan } \\
\text { apapun }\end{array}$ & $\begin{array}{l}\text { Pelanggarnya didenda } \\
\text { sebesar 100 }\end{array}$ \\
\hline
\end{tabular}

\begin{tabular}{|l|l|l|}
\hline 37 & $\begin{array}{l}\text { Pendatang (orang luar } \\
\text { desa) sama sekali tidak } \\
\text { diperkenankan untuk } \\
\text { memiliki tanah di wilayah } \\
\text { Desa Adat Tenganan } \\
\text { Pegringsingan }\end{array}$ & $\begin{array}{l}\text { Pelanggarnya didenda } \\
\text { uang sebesar setengah } \\
\text { harga tanah dan disita } \\
\text { tanahnya oleh desa adat }\end{array}$ \\
\hline $\mathbf{5 5}$ & $\begin{array}{l}\text { Penduduk Desa Tenganan } \\
\text { Pegringsingan mencuri/ } \\
\text { memetik buah-buahan: } \\
\text { buah durian, buah tehep, } \\
\text { pangi, tingkih. }\end{array}$ & $\begin{array}{l}\text { Pelanggarnya didenda } \\
\text { uang sebesar 2.000 }\end{array}$ \\
\hline $\begin{array}{l}\text { Pendatang (orang luar } \\
\text { desa) dilarang mencuri/ } \\
\text { memetik buah durian, buah } \\
\text { tehep, pangi, tingkih. }\end{array}$ & $\begin{array}{l}\text { Pelanggarnya didenda } \\
\text { uang sebesar 4.000 }\end{array}$ \\
\hline
\end{tabular}

Sumber: Awig-awig DesaAdatTenganan Pegringsingan

Seperti ditunjukkan pada Tabel 1, terdapat sejumlah pasal dalam awig-awig yang bertujuan untuk memproteksi dari segala tindakan yang secara langsung maupun tidak langsung bisa merusak hutan di Desa Adat Tenganan Pegingsringan.Diantara pasal awig-awig tersebut adalah pasal 3, pasal 8, pasal 10, pasal 37 dan pasal 55.Dalam pasal 3 disebutkan bahwa siapapun tidak diperkenankan mencuri hasil kebun di Desa Adat Tenganan Pegingsringan.Pelanggarnya diwajibkan mengganti 2 kali lipat hasil kebon yang dicuri tersebut atau dikenakan denda uang sebesar 2.000. Dalam pasal 3 juga disebutkan ahwa siapapun yang mencuri mas, perak, permata, mirah, intan ratna diwajibkan mengganti 2 kali lipat atas barang yang dicuri, dan dikenakan denda uang sebesar 10.000. Selanjutnya dalam awig-awig pasal 8 disebutkan bahwa siapapun dilarang menanam pohon tuwum (tarum), membikin gula, arak (air nira) dan menanam bawang merah, bawang putih.Bagi pelanggarnya didenda uang sebesar 400 dan tanahnya disita oleh desa.

Upaya memelihara lingkungan hidup di Desa Adat Tenganan Pegringsingan termuat dalam awig-awig pasal 10 dan pasal 37. Dalam pasal 10 disebutkan bahwa orang luar desa dilarang memungut reruntuhan buah-buahan apapun yang dihasilkan di kebon atau hutan Desa Adat Tenganan Pegringsingan.Pelanggarnya bisa dikenakan denda sebesar 100 .

Proteksi terhadap kemungkinan kerusakan hutan dari para pendatang (orang luar desa), bukan hanya berupa ketentuan pasal 10 yang melarang pendatang memungut buah-buahan, 
tetapi lebih dari itu, para pendatang (dalam pasal 37) juga tidak diperkenankan mengambil alih (membeli) tanah yang ada di wilayah Desa Adat Tenganan Pegringsingan. Untuk mengantisipasi kerusakan lingkungan hidup, awig-awig Desa Adat Tenganan Pegringsingan juga mengatur tentang larangan memetik buahbuahan secara sembarangan (Pasal 55).

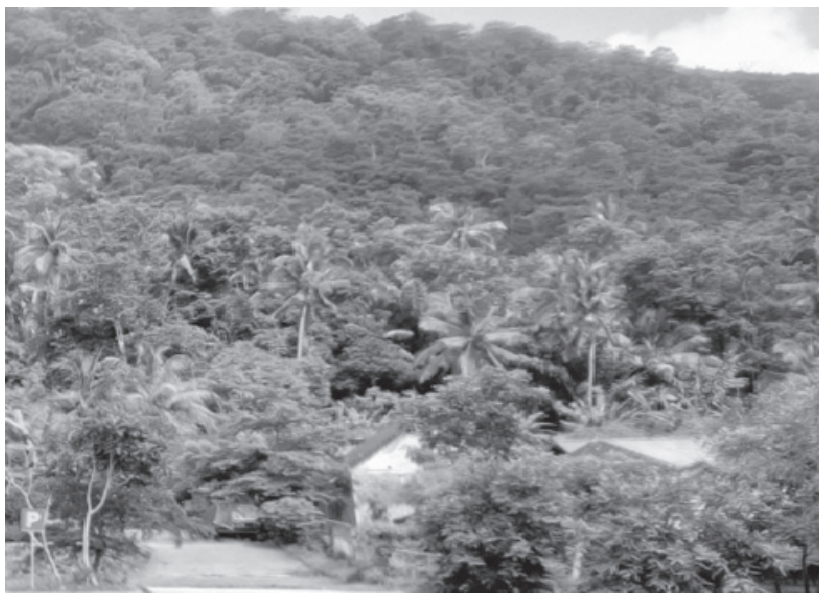

Gambar 3.1

Hutan Tenganan Pegringsingan

(Sumber: Karmini, 2019)

Demi menjaga keseimbangan lingkungan hidup, hak Penduduk Desa Adat Tenganan Pegringsingan dalam memanfaatklan hasil hutan dibatasi, termasuk pemanfaatan hasil bumi untuk keperluan upacara adat. Hal ini diatur dalam awig-awig Desa Adat Tenganan Pegringsingan pasal 38 yang menyebutkan bahwa jumlahsalaran (sumbangan wajib) di wilayah Tenganan yang bisa dipungut adalah: pisang yang berbuah pertama kalim tangkai (tandan) kelapa dalam sepohon, sirih lebih dari satu genggam, bambu dilarang dua batang dalam serumpun yang pantas memakai kisa (sejenis keranjang dari daun kelapa) wajib satu kisa berisi 12 biji (butir).

Pembatasan dalam pemanfaatan hasil bumi untuk keperluan upacara adat secara tegas diatur dalam awig-awig Desa Adat Tenganan Pegringsingan pasal 54. Dalam pasal 54 disebutkan bahwa (a) penduduk Desa Adat Tenganan Pegringsingan yang tidak mengeluarkan nira (saat upacara) dapat didenda uang sebesar 400; (b) penduduk Desa Adat TengananPegringsinganyangmenyelenggarakan upacara, berhak (mengambil dengan cumacuma hasil bumi: buah kelapa agar 7 butir, buah pisang setandan, buah pinang setandan, buah nangka sebutir, keladi 9 pohon yang sebidang, isen (tanaman sejenis kunir) 9 pohon, ubi kayu satu kisa (keranjang) isi 12 biji yang sebidang. Pembatasan pemanfaatan hasil hutan ini dimaksudkan agar potensi dan kesinambungan hasil produksi kebon/hutan setempat tetap terjaga.

Perlindungan Kawasan Hutan di Desa Adat TengananLuas wilayah lebih dari $80 \%$ berupa hutanyang bertumpu pada konsep agroforestry. Hutanmilik masyarakat dan dipelihara bersama dengan aturan sangat ketat yang dikoordinasi oleh kepaladesa. Prajuru adat dan pengurus desa setempat memiliki otoritas penuh dalam memegang kesepakatan yang telah tertulis dalam awig-awig, tunduk pada tanggung jawab dan sanksi terhadap pelanggaran. Realisasi perlindungan sumberdaya alam sebagai bentuk biofisik, untuk memperoleh kesempatan kerja sebagai satu nilai ekonomi, kehidupan sosial yang bersifat berkeadilan dan keputusan bersama secara transparan dan sangat demokratis (Permana, 2010).Hukum adat, berupa awig-awigmampu amengatur warga Desa Tenganan untuk hidup harmonis dengan lingkungannya.Awig-awigDesa Adat Tenganan Pegringsingan merupakan pengejawantahan hukum lingkungan adat setematyang mengatur perilaku lingkungan masyarakat, sehingga tercipta hubungan manusia dengan lingkungan hidup yang serasi, seimbang. Hal ini terjadi karena manusia Tenganan menganggap bahwa mereka merupakan bagian dari alam semesta. Terjadi harmonisasi kehidupan dan membentuk setiap orang dalam masyarakat sebagai pembina lingkungan yang bijaksana dan bertanggung jawab. Kebijaksanaan pengelolaan hutan semestinya dapat mengubah perilaku manusia dari yang cenderung untuk merusak alam menjadi pembina yang melestarikan lingkungan hidup secara seimbang.

\subsection{Implikasi Pengelolaan Hutan Bagi Upaya Pelestarian Lingkungan Hidup}

Penerapan awig-awig dalam pengelolaan hutan desa Tenganan memiliki sejumlah implikasi. Pertama, awig-awig mampu menjaga 
akelestarian Hutan Tenganan Pegringsingan. Kondisi hutan di wilayah Desa Adat Tenganan Pegringsingan masih asrimemiliki sejumlah vegetasi alam berupa pohon, semak atau perdu, dan buah-buahan yang masih dilindungi dan terkelola dengan baik.

Kedua, penerapan awig-awig mampu mendukung keajegan tata ruang.Sebagai bentuk kearifan lokal, awig-awig tidak dapat dilepaskan dari kehidupan sosial budaya, dan religi yang berkaitan dengan tata lingkungan pemukiman, tata pengelolaan sumber daya air dan tata pengelolaan perlindungan hutan (Senasri, 2008).Sistem penataan desa berlandasakan pada konsep dualistis (Rwa Bhineda), yaitu konsepsi adanya dua hal yang berlawanan Pola pemukiman mengelompok ditengahtengah desa yang dikeleilingi oleh bukit kangin, kauh dan kaja sedangkan di selatan merupakan pintu keluar Desa Adat Tenganan Pegringsingan menuju desa tetangganya Sedahan. Secara umum, struktur desa tersusun atas 4 (empat) arah mata angin yang sekaligus merupakan pintu (lawangan) dengan pusat terletak pada tegah- tengahnya, dengan fungsinya masingmasing (Gambar 2).

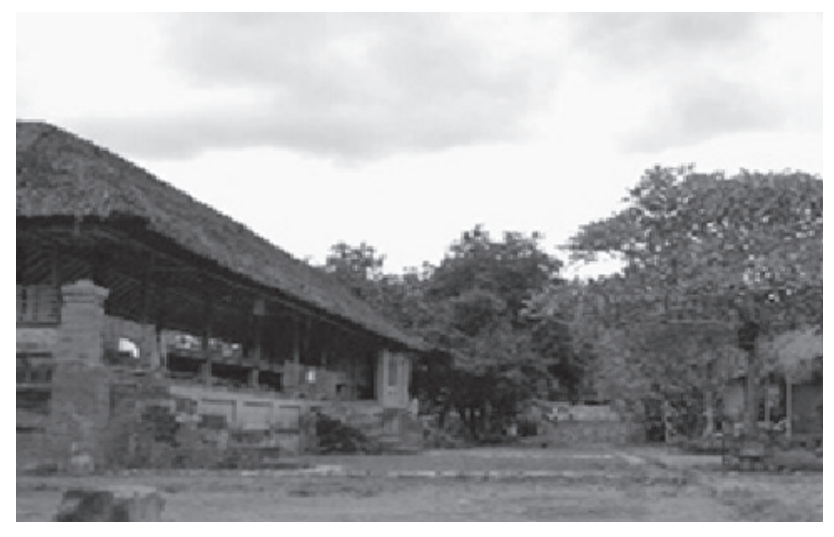

\section{Gambar 2 \\ Areal Pemukiman di Desa Adat Tenganan (Sumber: Karmini, 2019)}

Penerapan awig-awig dapat menjaga keajegan tata ruang wilayah DesaAdatTenganan Pegringsingan. Tata ruang ini antara lain dapat dilihat dari tata lingkungan pemukiman. Dalam tata lingkungan pemukiman, di Desa Tenganan Pegringsingan bentuk wilayah pemukimannya membujur dari Utara dan semakin merendah ke
Selatan, dengan pola perkampungan yang memusat.Sampai saat ini masyarakat Tenganan Pegringsingan masih menempati tanah pekarangan yang telah ditetapkan desa. Luas rata-rata per kepala keluarga 2 are dan total luas keseluruhan permukiman adalah 8,0 ha.

Penerapan awig-awig di Desa Tenganan Pegringsingsan juga menjaga kelestarian lingkungan hidup baik berupa sawah, tegalan dan hutan desa. Kawasan persawahan yang mencapai 255,840 ha ini berada di balik bukit hutan Tenganan Pegringsingsan sehingga tidak nampak dari daerah pemukiman.Warga sejumlah desa menggarapnya dengan sistem bagi hasil.Luas kawasan hutan 583,035 km persegi yang berada di dataran lebih tinggi dari permukiman.

"Kami selaku warga di sini memiliki keyakinan bahwa manusia adalah bagian dari alam.Tetumbuhanm, hewan dan segala mahluk hidup adalah bagian dari kehidupan kami.Untuk itu, hutan di sini kami lestarikan agar kami bisa tetap hidup secara seimbang - selaras dengan alam (Pance, 43 tahun, wawancara tanggal 9 Januari 2019).

Manusia mempunyai kewajiban menjaga dan melindungi makhluk hidup dan kawasan hutan. Perlindungan hutan adalah sebagai upaya perlindungan dirinya. Bumi merupakan satucomplex adapted system yang mampu menyesuaikan dirinya dalam menghadapi perubahan, terutama perubahan yang diakibatkan manusia. Penjagaan dan perlindungan kawasan hutan bermakna menjaga eksistensi kemanusiaan karena manusia merupakan salah satu tangga nada dalam kehidupan semesta (Purnama, 2010).

Ketiga, penerapan awig-awig menopang pariwisata berkelanjutan. Menurut Soemarwoto (1991: 69), strukturisasi dalam setiap hubungan manusia dengan lingkungan menyebabkan setiap perbuatan manusia terhadap lingkungan didasarkan pada aturan hukum yang mengikatnya sehingga prinsip kelestarian akan dapat dioptimalisasi hasilnya. Hal ini dikarenakan risiko lingkungan tidak saja terjadi secara alamiah, melainkan juga dapat melalui faktor teknologi dan sosial budaya lain, baik 
secara sengaja maupun secara tidak secara sengaja. Antara manfaat dan resiko lingkungan terdapat hubungan yang erat, suatu dapat merupakan manfaat dan risiko sekaligus, sehingga keterikatan antara manfaat dan resiko lingkungan nampak juga dari hal bahwa mengambil manfaat lingkungan selalu akan menimbulkan risiko lingkungan.

\subsection{Makna Pengelolaan Hutan Tenganan Sebagai Model Pendidiikan Lingkungan Hidup Bagi Generasi Milenial Pada Era 4.0}

Pada hakikatnya, pendidikan mencakup kegiatan melatih dan mendidik dalam rangka perkembangan peserta didik yang lebih baik. Pendidikan diperlukan untuk kehidupan sosial yang lebih baik dan kemudahan dalam pekerjaan. Selanjutnya mengatakan bahwa pendidikan sebagai proses panjang agar peserta didik lebih survive dalam perubahan kehidupan (Saroni, 2011:10).

Sikap dan perilaku adaptif masyarakat adat Tenganan dalam mengelola hutan setempat merupakan media pendidikan bagi anak-anak terkait sekap manusia terhadap lingkungan alamnya.Masyarakat adat Tenganan sejak dini telah melibatkan anak-anak dan generasi milenial dalam mengelola potensi hutan setempat. Hal ini berarti, upaya menjaga kelestarian hutan (lingkungan hidup) di wilayah Desa Adat Tenganan telah menyertakan generasi milenial melalui proses pewarisan budaya dari generasi ke generasi selanjutnya melalui proses pembelajaran yang berlangsung secara formal dan informal. Proses pembelajaran formal berlangsung sejak anak-anak di bangku PAUD sampai perguruan tinggi (PT), sedangkan proses pendidikan informal berlangsung melalui enkulturasi (pembudayaan) dan sosialisasi di lingkungan keluarga. Seperti kata Anthony Gidden (2003), peran orang tua begitu penting untuk melakukan sosialisasi dan enkulturasi (proses pembudayaan) nilai-nilai budaya kepada anak selaku generasi penerus.

Sejak dini, anak-anak Tenganan telah mentaati awig-awig (kearifan lokal) untuk amenjaga alam lingkungannya.Mereka dialtih untuk berperialku yang mendukung upaya pelestarian lingkungan hidup.Penerapan kearifan lokal (awig-awig) dalam mengelola hutan Tenganan secara daptif memiliki implikasilangsung dalam menumbuhkan perilaku yang mendukung upaya pelestarian lingkungan hidup. Upaya pelestarian lingkungan hidup merupakan bentuk dari pembangunan berkelanjutan (sustainable development), yakni sebuah proses pembangunan yang mengoptimalkan manfaat dan kesesuaian dari sumber daya alam dan sumber daya manusia yang tersedia. "Berkelanjutan" dapat diartikan kelestarian yang menyangkut aspek fisik, sosial, dan politik dengan memperhatikan pengelolaan sumber daya alam (resources management) yang mencakup hutan, tanah, dan air, pengelolaan dampak pembangunan terhadap lingkungan, serta pembangunan sumber daya manusia (human resources development). Kondisi ini dapat tercapai apabila perangkat kelembagaan memasukkan unsur-unsur multisektor yang mencakup pemerintah, swasta, LSM, serta badan-badan internasional.

Upaya pelestarian lingkungan hidupdi Desa Adat Tenganan juga sebagai langkah kosntruktif dalam mendukung pembangunan pariwisata. Pariwisata sebagai salah satu sektor pembangunan tidak dapat dilepaskan kaitannya dengan pembangunan berkelanjutan yang telah dicanangkan oleh pemerintah sesuai dengan tujuan pembangunan nasional. Pariwisata yang bersifat multisektoral merupakan fenomena yang sangat kompleks dan sulit didefinisikan secara baku untuk diterima secara universal. Sehingga menimbulkan berbagai persepsi pemahaman terhadap pariwisata, baik sebagai industri, sebagai aktivitas, atau sebagai sistem.

Dengan memelihara keasrian dan upaya pelestarian lingkungan hidup, masyarakat Desa Adat Tenganantelah menjadi subjek pembangunan pariwisata berkelanjutan di desanya. Di samping ingin mengembangkan kesejahteraan ekonomi, mereka tetap berupaya untuk melestarikan lingkungan hidup (ekologis) dan tradisi budaya Bali. Dengan demikian pengembangan ekowisata di Tenganan didukung oleh adanya kapasitas ekologi (kemampuan lingkungan alam untuk memenuhi kebutuhan wisatawan), kapasitas fisik (kemampuan sarana dan prasarana untuk memenuhi kebutuhan wisatawan), dan kapasitas sosial (kemampuan 
daerah tujuan untuk menyerap pariwisata tanpa menimbulkan dampak negatif pada masyarakat lokal), serta kapasitas ekonomi (kemampuan daerah tujuan untuk menyerap usaha-usaha komersial namun tetap mewadahi kepentingan ekonomi lokal).

Desa Adat Tenganan telah menjadi salah satu tujuan wisata di Bali yang dikunjungi wisatawan nusantara dan mancanegara.Daya tarik Desa Tenganan bukan hanya pada objek wisata yang berupa keindahan alamnya, tetapi juga tradisi budaya masyarakat desa setempat yang unik. Upaya pelestarian lingkungan hidup di Desa Tenganan sesuai dengan prinsip-prinsip pembangunan pariwisata berkelanjutan, yakni pembangunan obyek dan daya tarik wisata dilakukan dengan memperhatikan: (a). Kemampuan untuk mendorong peningkatan perkembangan kehidupan ekonomi dan sosial bangsa ; (b). Nilai-nilai agama, adat istiadat, serta pandangan dan nilai-nilai yang hidup dimasyarakat ; (c). Kelestarian budaya dan mutu lingkungan hidup ; (d). Kelangsungan usaha pariwisata itu sendiri (UU No. 9/1990, Pasal 6).

Upaya penegakan awig-awig untuk menjaga pelestarian dan keasrian lingkungan hidup Desa Adat Tenganan amat diperlukan. Hal ini sesuai dengan Kode Etik Pariwisata (WTO) yang menyatakan bahwa: "Pariwisata, faktor pembangunan berkelanjutan "(Pasal 3; Majelis Umum WTO, 1999). Selain itu, upaya pelestarian hutan di Desa Adat Tenganan amat mendukung prinsip pembangunan pariwisata berkelanjutan sesuai dengan Tri Hita Karana, yakni konsep yang terkait dengan kebahagiaan lahir batin masyarakat Hindu Bali. Menurut Mantra (1996), Tri HitaKarana adalah keseimbangan antara manusia dengan sesamanya (Pawongan), manusia dengan lingkungannya (palemahan) dan hubungan manusia dengan TuhanNya (parahyangan).Upaya penegakanprinsip Tri Hita Karana (THK) akan berarti bagi pembangunan pariwisata Bali yang berkelanjutan. Paradigma pariwisata budaya berkelanjutan meliputi: terpeliharanya mutu sumber daya alam dan budaya, meningkatnya kesejahteraan masyarakat lokal, dan terwujudnya kepuasan wisatawan (Ardika, 2006).

Sikap dan perilaku masyarakat Tenganan dalam mengelola hutan secara adaptif merupakan suatu model pendidikan langsung bagi anak milenial setempat dalam upaya pelestarian lingkungan hidup.Proses pendidikan generasimilenial yangadaptif terhadap alam tersebut sesuai dengan prinsip pendidikan di era revolusi industry 4.0 dewasa ini yang mencakup olah pikir, olah rasa/karsa , olah raga , olah hati sehingga tercipta pribadi-pribadi yang memiliki karakter yang sehat cerdas, jujur dan berintegritas, peduli, tangguh, mandiri, nasionalis dan religious (Ristekdikti, 2018; Mulyana, 2004). Selain itu, generasi milenial juga wajib menjaga planet bumi, menjaga keseimbangan ekosistem dan menjadi pelopor dalam merawat, melestarikan lingkungan hidup. Setidaknya, terdapat tiga sikap pengembangan industri terhadap lingkungan hidup di era 4.0 dewasa ini, yakni sikap redistributif, restoratif, dan regeneratif.Industri redistributive ialah upaya menjaga keseimbangan antara faktor ekonomi dengan pelestarian lingkungan hidup. Industri restoratif ialah industri yang sudah memperhatikan dan memperbaiki mutu lingkungan. Selanjutnya tahap regeneratif yaitu ekonomi yang meningkatkan daya dukung lingkungan. Selain itu, era revolusi industri 4.0 akan mempermudah dalam pemantauan pencemar dan perubahan iklim global melalui data-data lingkungan yang dapat diakses dengan mudah serta mampu menjadi early warning system dalam mengatasi permasalahan yang ada (Anonim. 2019).

\section{SIMPULAN DAN SARAN}

\subsection{Simpulan}

Bentuk pengelolaan hutan di Desa Adat Tenganan diperkuat dengan implementasi kearifan lokal (awig-awig). Komunitas Bali aga setempat melaksanakan awig-awig tersebut. Mereka tidak merusak potensi flora dan fauna hutan, serta memanfaatkan hasil hutan secara adaptif. Penerapan kearifan lokal (awig-awig) dalam mengelola hutan Tenganan secara adaptif memiliki implikasi langsung dalam menumbuhkan perilaku yang mendukung upaya pelestarian lingkungan hidup. Pengelolaan hutan secara adaptif memiliki makna bagi 
pendidikan lingkungan hidup untuk generasi milenial.

\subsection{Saran}

Upaya melestarikan hutan dan lingkungan hiup pada era 4.0 amat penting.Untuk itu, pelibatan generasi milenial dalam upaya pelestarian lingkungan hidup perlu terus dikembangkan.

\section{DAFTAR PUSTAKA}

Anonim. 2019. Revolusi Industri 4.0 Menjadi Tantangan Kelestarian Lingkungan Hidup; 20 Februari 2019; https://www.greeners.co/berita/revolusi-industri-4-0-menjadi-tantangankelestarian-lingkungan-hidup/

Ardika, I Wayan. 2006. "Pengelolaan Pusaka Budaya sebagai Obyek dan Daya Tarik Pariwisata Bali" (dalam Bali Bangkit Kembali). Denpasar: Departemen Kebudayan dan pariwisata RI dan Universitas Udayana.

Astiti, Tjok Istri Putra. 2005. Awig-Awig Sebagai Sarana Pelestarian Lingkungan Hidup. Denpasar: PPLH Lemlit Universitas Udayana.

Awig-awig Desa Adat Tenganan Pegringsingan

Budeanu, Adriana. (2007). "Sustainable Tourist Behavior : A Discussion of Opportunities For Change", International Journal of Customer Studies, 31, pp. 499-508.

Bungin, Burhan. (2015). Metodologi Penelitian Kualitatif. Depok: Rajagrafindo.

Damanik, Janianton dan Weber, Helmut.(2006). Perencanaan Ekowisata Dari Teori ke Aplikasi. Yogyakarta : PUSPAR UGM dan Andi.

Giddens, A. 2003. The Constitution of So-ciety : Teori Strukturasi untuk Analisis Sosial (D. A. L. Sujono, Trans.). Pasuruan: Penerbit Pedati.

Majelis Umum dari Kode.1999. WTO Organisasi Pariwisata Dunia Global Etik Pariwisata.

Mantra, Ida Bagus. 1996. Landasan Kebudayaan Bali. Denpasar: Yayasan Dharma Sastra.

Muhammad Saroni. (2011). Orang miskin bukan orang bodoh. Yogyakarta: BahteraBuku

Peraturan Daerah (Perda) Penataan Kawasan Pariwisata Kabupaten Karangasem Nomor 8 Tahun 2003

Mulyana, Rohmat. 2004. Mengatikulasi Pendidikan Nilai. Bandung: Alfabeta.

Peraturan Daerah Provinsi Bali Nomor 2 Tahun 2012 Tentang Kepariwisataan Budaya Bali.

Permana dkk. 2010.Perubahan Pola Ruang Tradisional Desa adat Tenganan Pegringsingan”. EJournal (Volume 3 Nomor 1, November 2010) Fakultas Teknik Universitas Brawijaya, Malang.

Piskorski, Mikolaj Jan. (2011).Social Strategies That Work.Cambridge :Harvard Business Press.

Pitana dan Gayatri.(2005). Sosiologi Pariwisata. Yogyakarta: Andi.

Ristek Dikti. 2018. Urgensi Audit Teknologi Di Era Revolusi Industri 4.0; https://ristekdikti.go.id/ wp-content/uploads/2018/12/20181207094442_MG_9644-01-180x110-1.jpeg

Ristekdikti. 2018. Mempersiapkan SDM Indonesia di Era Industri 4.0 (Bahan Presentasi). Jakarta: Kementerian Riset, Teknologi dan Pendidikan Tinggi 2018; http://sdgcenter.unpad.ac. id/wp-content/uploads/2018/09/ Kemenristek dikti-Mempersiapkan-SDM-Indonesiadi-Era-Industri-4.0.pdf 
Sabri, L., \& Hastono, S. P. (2006).Statistik Kesehatan.Jakarta : PT Raja Grafindo Persada.

Sadulloh, Uyoh.2011. Pedagogik. Bandung: Alfabeta.

Senastri, Ni Made Jaya. 2008. Pengelolaan Lingkungan Hidup Berdasarkan Prinsip- Prinsip Kearifan Lokal (Studi di Desa Tenganan Pegringsingan, Kecamatan Manggis, Kabupaten Karangasem, Provinsi Bali)" (Tesis). Jember: Program Studi Magister Ilmu Hukum, Pascasarjana, Universitas Jember.

Soemarwoto, Otto. 1991. Ekologi, Lingkungan Hidup dan Pembangunan. Jakarta: Djambatan. Soemarwoto, Otto. 1994.Ekologi Lingkungan Hidup dan Pembangunan. Jakarta :Djambatan. Undang-undang No. 9 Tahun 1990 tentang Kepariwisataan

Undang-Undang No 32 Tahun 2009 tentang Perlindungan dan Pengelolaan Lingkungan Hidup Wang, Y. and Wall, G. (2005). Sharing the Benefits of Tourism : A Case Study in Hainam, China. Environments, 33 (1); hal $41-59$.

Wihadanto, Firmansyah. 2013. Mengatasi Ketimpangan Pembangunan Antar Wilayah Melalui Mekanisme Kompensasi Di Era Otonomi Daerah : Studi Kasus Provinsi Bali. (Prosiding Seminar Nasional FISIP-UT), Transformasi Kepemimpinan Nasional Menuju Masyarakat Madani (ISBN : 978-979-011-827-0). 